Van Wilgenburg, S. L., E. M. Beck, B. Obermayer, T. Joyce, and B. Weddle. 2015. Biased representation of disturbance rates in the roadside sampling frame in boreal forests: implications for monitoring design. Avian Conservation and Ecology 10(2):5. http://dx.doi.org/10.5751/ACE-00777-100205 Copyright (C) 2015 by the author(s). Published here under license by the Resilience Alliance.

Research Paper

\title{
Biased representation of disturbance rates in the roadside sampling frame in boreal forests: implications for monitoring design
}

\author{
Steven L. Van Wilgenburg ${ }^{1}$, Elizabeth M. Beck ${ }^{1}$, Brennan Obermayer ${ }^{2}$, Timothy Joyce ${ }^{2}$ and Brett Weddle ${ }^{2}$ \\ ${ }^{1}$ Environment Canada, Canadian Wildlife Service, ${ }^{2}$ Sir Sanford Fleming College
}

\begin{abstract}
The North American Breeding Bird Survey (BBS) is the principal source of data to inform researchers about the status of and trend for boreal forest birds. Unfortunately, little BBS coverage is available in the boreal forest, where increasing concern over the status of species breeding there has increased interest in northward expansion of the BBS. However, high disturbance rates in the boreal forest may complicate roadside monitoring. If the roadside sampling frame does not capture variation in disturbance rates because of either road placement or the use of roads for resource extraction, biased trend estimates might result. In this study, we examined roadside bias in the proportional representation of habitat disturbance via spatial data on forest "loss," forest fires, and anthropogenic disturbance. In each of 455 BBS routes, the area disturbed within multiple buffers away from the road was calculated and compared against the area disturbed in degree blocks and BBS strata. We found a nonlinear relationship between bias and distance from the road, suggesting forest loss and forest fires were underrepresented below 75 and $100 \mathrm{~m}$, respectively. In contrast, anthropogenic disturbance was overrepresented at distances below $500 \mathrm{~m}$ and underrepresented thereafter. After accounting for distance from road, BBS routes were reasonably representative of the degree blocks they were within, with only a few strata showing biased representation. In general, anthropogenic disturbance is overrepresented in southern strata, and forest fires are underrepresented in almost all strata. Similar biases exist when comparing the entire road network and the subset sampled by BBS routes against the amount of disturbance within BBS strata; however, the magnitude of biases differed. Based on our results, we recommend that spatial stratification and rotating panel designs be used to spread limited BBS and off-road sampling effort in an unbiased fashion and that new BBS routes be established where sufficient road coverage exists.
\end{abstract}

\section{Représentativité biaisée des taux de perturbation dans le plan d'échantillonnage en bord de routes en forêt boréale : répercussions dans l'élaboration de suivis}

RÉSUMÉ. Le Relevé des oiseaux nicheurs (BBS) nord-américain est la principale source de données sur le statut et la tendance des oiseaux de la forêt boréale pour les chercheurs. Malheureusement, la couverture du BBS en forêt boréale est faible et les préoccupations grandissantes sur le statut des espèces nichant dans ce milieu ont amené les chercheurs à considérer étendre la couverture du BBS vers le nord. Toutefois, les taux élevés de perturbation en forêt boréale pourraient compliquer les suivis effectués le long des routes. Si l'échantillonnage réalisé en bord de routes ne tient pas compte des taux de perturbation variables tant dans l'emplacement des routes que dans l'utilisation des routes pour l'extraction des ressources, les estimations de la tendance qui en résultent pourraient être faussées. Nous avons examiné si les suivis en bord de routes pouvaient présenter un biais quant à leur représentativité proportionnelle des perturbations d'habitat au moyen de données spatiales sur la «perte» de forêts, les feux de forêt et les perturbations anthropogéniques. Pour chacun des 455 parcours BBS, la superficie perturbée dans diverses bandes de distance du bord des routes a été calculée et comparée à la superficie perturbée dans des quadrilatères d'un degré et des strates du BBS. Nous avons observé une relation non linéaire entre le biais et la distance à la route, ce qui laisse croire que la perte de forêt et les feux de forêt étaient sous-représentés pour des distances inférieures à 75 et à $100 \mathrm{~m}$, respectivement. À l'opposé, les perturbations anthropogéniques étaient surreprésentées pour des distances inférieures à $500 \mathrm{~m}$ et sous-représentées au-delà de cette distance. Une fois la distance à la route prise en compte, les parcours BBS étaient raisonnablement représentatifs du quadrilatère d'un degré dans lequel ils se trouvaient; seulement quelques strates présentaient une représentativité biaisée. Dans l'ensemble, les perturbations anthropogéniques étaient surreprésentées dans les strates du sud et les feux de forêt étaient sous-représentés dans presque toutes les strates. Des biais similaires ont été obtenus lorsque nous avons comparé les quantités de perturbations présentes dans le réseau routier en entier et le sous-ensemble échantillonné par le BBS avec les quantités présentes dans les strates entières du BBS, bien que leur ampleur différait. Selon nos résultats, nous recommandons d'une part d'adopter des plans d'échantillonnage fondés sur une stratification spatiale et une rotation afin d'étendre d'une façon non biaisée l'effort limité d'échantillonnage du BBS et des suivis hors routes et, d'autre part, d'établir de nouveaux parcours BBS là où il y a suffisamment de routes.

Key Words: BBS; bias; boreal forest; disturbance; forest fire; North American Breeding Bird Survey; roadside sampling 


\section{INTRODUCTION}

Numerous species of birds have significant proportions of their breeding populations within the boreal forest (Wells and Blancher 2011). For example, Wells and Blancher (2011) estimated that 35 species likely have $\geq 80 \%$ of their global population in the boreal forest. Despite the obvious importance of the boreal forest as a breeding area for North America's avifauna, there is a lack of onthe-ground monitoring from which to estimate population status and trends (Avian Monitoring Review Steering Committee 2012, Machtans et al. 2014). Given increased concern over resource development (Schindler and Lee 2010) and the potential impacts of climatic change (Schindler and Lee 2010, Stralberg et al. 2015), there is increasing interest in northward expansion of monitoring efforts (Avian Monitoring Review Steering Committee 2012, Machtans et al. 2014).

Regardless of current monitoring coverage or lack thereof in boreal regions, the North American Breeding Bird Survey (BBS; Sauer and Link 2011) remains the principal data source for status and trend assessment for the majority of boreal forest birds. Because of the broad coverage and the large database that has been amassed over almost 50 years, the BBS has become the backbone of conservation assessments and planning for most passerines in North America (Veech et al. 2012). BBS data are frequently used in status assessments under federal and provincial species-at-risk acts and associated recovery efforts. For example, the Canada Warbler (Cardellina canadensis) and Olive-sided Flycatcher (Contopus cooperi) were recently listed as threatened under Canada's Species At Risk Act (S.C. 2002, c. 29), in large part because of trends estimated from the BBS (Machtans et al. 2014). Unfortunately, BBS coverage is largely limited to the southern periphery of the boreal forest, which may introduces bias in estimates of species status or trends (O'Connor et al. 2000, Matsuoka et al. 2011, Machtans et al. 2014) and thereby introduce greater uncertainty in species status assessments (Machtans et al. 2014).

The lack of data and potential spatial coverage biases in BBS effort across the boreal forest increases the risk of inaccurate trend estimation and also makes it difficult to distinguish changes in population size from spatio-temporal shifts in distribution (e.g., Wilson et al. 2013). Matsuoka et al. (2011) demonstrated that boreal BBS coverage is disproportionately biased toward southern ecozones. Recent data from Machtans et al. (2014) demonstrated that off-road monitoring in a $\sim 2600-\mathrm{km}^{2}$ area of the Northwest Territories, which is outside normal BBS coverage, resulted in population trend estimates that were poorly correlated with BBS trends from strata south of their study area. There may be several alternative hypotheses to explain the Machtans et al. (2014) results, including the possibility that large-scale factors such as climate may make extrapolation of BBS trends to unsampled areas difficult. Although the Machtans et al. (2014) data are limited in scope, comparison of trends between BBS and migration monitoring analyses demonstrates a strong correlation between trend estimates when comparing across southern distributed species, which are well sampled by the BBS, but poor correlations for northern distributed species (Crewe et al. 2008). Together, these lines of evidence suggest the possibility that northern species could be inappropriately listed as species of concern when it may not be warranted (Martin et al. 2007, Machtans et al. 2014), which could result in inappropriate allocation of scarce resources for conservation (Rice 2003). Conversely, there is a possibility of missing changes in status that would otherwise warrant conservation action for species largely distributed north of current BBS sampling.

Estimation and interpretation of species status and trends in the boreal forest may be further complicated if spatial coverage bias interacts with other factors. It has long been recognized that roadside sampling may result in biased habitat representation (O'Connor et al. 2000, Lawler and O'Connor 2004, Veech et al. 2012) and that habitat biases exist in boreal BBS coverage (Blancher, unpublished report, cited in O'Connor et al. 2000, Matsuoka et al. 2011). In addition, several systematic changes in spatial distribution of habitats occur in the boreal forest (e.g., increasing proportion of coniferous trees toward the treeline) that could interact with spatial distribution of effort. Simulation studies have shown that land cover sampling biases can introduce biases in both estimated status and trend (Harris and Haskell 2007). Furthermore, bias in representing landscape change along BBS routes could result in biased population trend estimates (O'Connor et al. 2000).

The interaction between disturbance rates and the distribution of BBS coverage may present a particularly difficult problem for monitoring in the boreal forest because of the high rates of natural and anthropogenic disturbance occurring there. Anthropogenic disturbances such as agriculture, forestry, mining, and oil and gas developments are clustered along the southern edge of the boreal forest (Hobson et al. 2002, Pasher et al. 2013). Thus, BBS coverage clustered along the southern periphery of the boreal forest is associated with an established and expanding human footprint (Cumming et al. 2001, Hobson et al. 2002, Schindler and Lee 2010, Van Wilgenburg et al. 2013). Conversely, the primary natural disturbance in the boreal forest, i.e., forest fire, is spatially variable, but tends to occur at higher rates in areas well north of current BBS sampling, with fire return intervals averaging 130-700 years across Canada (Stocks et al. 2002, Bergeron et al. 2004), but these intervals can be as low as 50 years in some northern regions (Belleau et al. 2007). Furthermore, the distribution of the road network within these regions may compound these potential biases because road construction is less likely to occur in lowland coniferous stands, e.g., bogs, where forest fire tends to burn larger areas compared with upland deciduous stands (Cumming 2001).

Given the interest in expanding monitoring efforts in the boreal forest, the historic strengths of the BBS, and potential biases associated with roadside sampling, our objective was to investigate potential biases in application of roadside sampling in the boreal forest to inform any expansion in monitoring efforts. A failure of the roadside sampling frame to accurately reflect disturbance rates over the population of interest would inherently result in biased trend estimates (e.g., Betts et al. 2007) and potentially affect sample size requirements. Therefore, we examined biases in BBS representation of habitat disturbance in the boreal forest. We hypothesized that roadside sampling in southern strata would show an overrepresentation of anthropogenic disturbances, whereas northern strata would display an underrepresentation of disturbance caused by fire. In addition, we hypothesized that anthropogenic disturbances would be disproportionately represented in areas immediately adjacent to roads, with declining representation away from roads. 


\section{METHODS}

We examined biases in roadside representation of disturbance rates using geospatial analyses of remotely sensed data representing overall forest "loss" (Hansen et al. 2013), anthropogenic disturbances (Pasher et al. 2013), and forest fires (Canadian Wildland Fire Information System 2014). Data representing anthropogenic disturbances were created to aid in boreal caribou conservation in Canada and were not collected over all boreal bird conservation regions (BCRs; Pasher et al. 2013). Therefore, we limited the geographic extent of our analyses to portions of the BBS strata that fall within those regions of the boreal forest for which we could obtain data from all three data sets (Fig. 1). All analyses were conducted using the ArcGIS v. 10.1 (ESRI, Redlands, California, USA) Geographic Information System (GIS). Prior to all analyses, all data layers were reprojected into the Albers equal-area conic projection to accurately represent area across the entire study area.

Fig. 1. Distribution of assigned and unassigned North American Breeding Bird Survey (BBS) routes and study area extent based on the portion of boreal Canada for which anthropogenic disturbance data (Pasher et al. 2013) are available. BCR indicates bird conservation region.

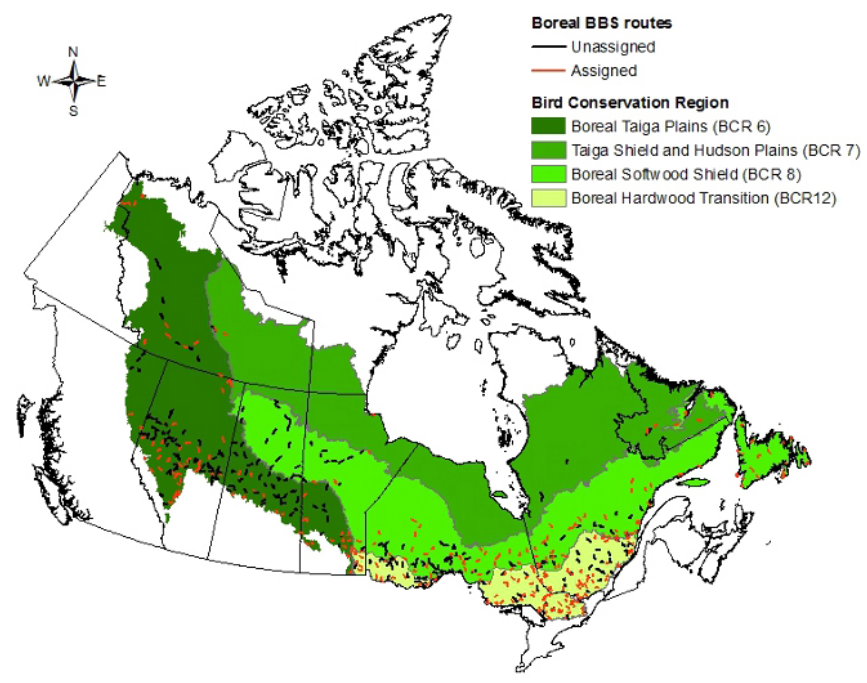

\section{Data set descriptions and manipulation}

\section{Forest change}

We obtained geospatial data representing overall forest loss using the Global Forest Change (2000-2012) database derived from Hansen et al. (2013). In brief, Hansen et al. (2013) derived a time series of percent tree (vegetation $\geq 5 \mathrm{~m}$ tall) cover from multitemporal growing-season Landsat 7 Enhanced Thematic Mapper Plus (ETM+) images from across the globe. Following classification, they used bagged decision trees to predict forest/ nonforest classes and summarized forest loss and gain into annual estimates using decision rules based on the maximum annual decline in percent tree cover and the maximum annual decline in the minimum growing season normalized vegetation difference index. The resulting data, therefore, provide estimated forest loss and gain at $\sim 30-\mathrm{m}$ resolution (Hansen et al. 2013). Here, we only focused on forest loss pixels as a measure of habitat change. Over much of the boreal forest, the forest loss variable primarily represents temporary change of forest cover to early successional forest types; however, permanent deforestation may be locally represented depending on the mechanism of forest change. Here, we refer to forest change as forest loss throughout to remain consistent with data used herein as available from Hansen et al. (2013).

\section{Forest fires}

To examine biases in sampling of early postfire areas, we accessed data from the Canadian National Fire Database (Canadian Wildland Fire Information System 2014), which contain geospatial polygons delineating the boundaries of large ( $\geq 100 \mathrm{ha})$ forest fires in Canada. We extracted all forest fire polygons that occurred between 2000 and 2012 and converted them to a single raster, i.e., pixel-based representation, representing whether a fire did (1) or did not (0) occur and set the spatial resolution to match the forest change database.

\section{Anthropogenic disturbances}

Pasher et al. (2013) manually digitized anthropogenic disturbances in the boreal forest between 2008 and 2010 by interpreting color composite imagery (generally bands 5, 4, 3 and $4,3,2$ ) from Landsat 5 or Landsat $7 \mathrm{ETM}+$, and digitizing disturbances visible at a 1:50,000 scale, using a 2-ha minimum mapping unit for polygon features. We obtained the raw polygon and line feature data in ESRI shapefile format from the authors (Pasher et al. 2013) and converted these to raster format at the same spatial resolution as the forest change database.

\section{GIS analyses}

We obtained a geodatabase from the Canadian Breeding Bird Survey office (Environment Canada), which provided line features representing the spatial location of Canadian BBS routes. We conducted a buffer analysis to identify the area of forest loss (2000-2012), forest fires (2000-2012), and anthropogenic disturbance (circa 2010) along each BBS route. We used multiple ring buffer analysis in the Analysis toolpack to create buffers at multiple distances from the road to allow us to examine whether anthropogenic disturbance was disproportionately represented immediately adjacent to roads. We created 20 different buffers along each route, with buffers every $25 \mathrm{~m}$ from $25-150 \mathrm{~m}$ from the road, then every $100 \mathrm{~m}$ from $200-1500 \mathrm{~m}$ from the road. A unique identifier was created for each combination of route and buffer distance, and this was subsequently used as a "zone field" in Spatial Analyst "Zonal Statistics as Table" queries to generate the total area of forest loss within the given buffer distance along each BBS route. The same zonal statistic queries were repeated for forest fires and anthropogenic disturbances.

We also conducted GIS analyses to determine the area of forest loss, forest fire, and anthropogenic disturbance at three other geographic scales against which disturbance along BBS routes could be compared. Because sample allocation within the BBS is currently based on pseudorandom sampling of latitude/longitude degree blocks (Bled et al. 2013), we quantified the total area of forest loss, forest fire, and anthropogenic disturbance in polygons 
representing BBS degree blocks using the same zonal statistics (methods as described above), where zones were represented by degree blocks. We also conducted the same analyses within a 400$\mathrm{m}$ buffer around the entire road network from road-segment shapefiles from the CanVec database (Natural Resources Canada 2011), as well as within polygons defining individual BBS strata that are defined by the intersection of provincial boundaries and BCRs (see Fig. 1). It is important to note that the road layer we used does not include many small forestry haul roads and other resource access roads. With approximately 2000 data sets missing nationwide, the majority in the Northwest Territories $(\mathrm{O}$. Trottier, personal communication), these other road networks could yield results different from those we present. The layer we used is similar to that used by the Breeding Bird Survey office, which aims to select roads that are accessible by BBS volunteers with any car and could be repeatable through time (M.-A. Hudson, personal communication). Thus, our results reflect biases inherent in the potential roadside sampling frame of the BBS.

\section{Statistical analysis}

All analyses were conducted by treating bias as the response variable, where bias was calculated as the percentage of area disturbed within the BBS buffer minus the percentage of area disturbed within the unit of comparison (degree block or BBS strata, see below). Thus, our response variable represents bias in the proportional representation between the route and the region it is supposed to be representing, with negative values indicating underrepresentation of area disturbed along the BBS route and positive values indicating overrepresentation along the BBS route. In the case of the forest loss and forest fire variables, these values represented cumulative areas over the 2000-2012 time intervals.

We examined bias between route buffers and degree blocks using Generalized Additive Mixed Models (GAMM; Zuur et al. 2009). Our GAMM models include fixed effects for strata, a cubic spline smoother for distance from the BBS route, and a random effect for BBS route to account for multiple measures of bias along the same route. Cross-validation was used to automatically determine the optimal amount of smoothing (Wood 2004, 2011); this was further verified by comparing models with different numbers of knots and using Akaike's Information Criterion scores to select the best model. Models were validated through visual examination of residual QQ-plots and histograms for normality, and plots of residuals versus fitted values for homogeneity (Zuur et al. 2009). All analyses were conducted using the mgcv package in the $\mathrm{R}$ statistical computing environment (version 3.1.1; $\mathrm{R}$ Development Core Team 2014).

In addition to the above sample-based analyses, we also calculated the bias in the representation of disturbances along all BBS routes (population level) relative to the total area of those disturbances within a given BBS stratum. Following Veech et al. (2012), we based these analyses on areas within $400 \mathrm{~m}$ of the BBS routes. Because these analyses are based on the whole population, there are no associated measures of variation; thus, we graphically present absolute differences between BBS routes and strata (excluding BCR 12, for which results are described in text only) with no further statistical analyses. Finally, we repeated this analysis based upon buffering the entire boreal forest road network by $400 \mathrm{~m}$ to examine whether biases may simply relate to a lack of sampling, and we used paired $t$ tests to compare whether bias in representation of disturbance along the whole road network is comparable to bias along the subset sampled by the network of BBS routes.

\section{RESULTS}

We conducted GIS analysis on a total of 455 BBS routes, 267 of which are currently assigned to BBS observers and thus potentially are contributing data to trend analyses. Baseline estimates of rates of forest disturbance at the scale of individual BBS strata were highly variable (Table 1). We estimated that the percentage of individual strata that were disturbed between 2002 and 2012 varied from $0.4 \%$ to $20.0 \%$ (median $=5.9 \%$ ), with rates being highest in BCRs 7 and 8 in Alberta and Saskatchewan (Table 1). The majority of forest loss appears to have been associated with forest fires, which disturbed between $0.0 \%$ and $20.0 \%$ $($ median $=1.5 \%)$ of the strata $($ Table 1$)$. Area of anthropogenic disturbances was generally slightly lower, representing $0.0 \%-15.7 \%($ median $=0.3 \%)$ of the area $($ Table 1$)$.

\section{Forest change}

Bias in representation of forest loss differed between strata $\left(\mathrm{F}_{17}\right.$ $\left.{ }_{438}=2.10, P=0.005\right)$; however, of the $17 \mathrm{BBS}$ strata containing routes, only 2 had BBS routes that were not representative of the degree blocks they were in (Appendix 1, Table A1.1). Specifically, forest loss was overrepresented along BBS routes in BCR 12 in Manitoba $(\beta=3.41 \%, \mathrm{SE}=1.71, t=1.99, P<0.05)$ and $\mathrm{BCR} 7$ in Québec $(\beta=13.60 \%, \mathrm{SE}=2.80, t=4.86, P \leq 0.001)$. In addition to strata level biases, we found a nonlinear relationship between bias and distance from road $(F=96.43$, effective degrees of freedom [edf] $=8.87, P \leq 0.001$ ) that suggested forest loss was underrepresented at distances below approximately $75 \mathrm{~m}$ and slightly overrepresented from $\sim 75-500 \mathrm{~m}$ (Fig. 2A).

Fig. 2. Generalized additive model results of the relationship between distance and the bias in representation of (A) forest "loss," (B) forest fires, and (C) anthropogenic disturbance between North American Breeding Bird Survey routes and degree blocks. Mean predicted bias (solid line) and 95\% confidence intervals (dashed lines) are given.
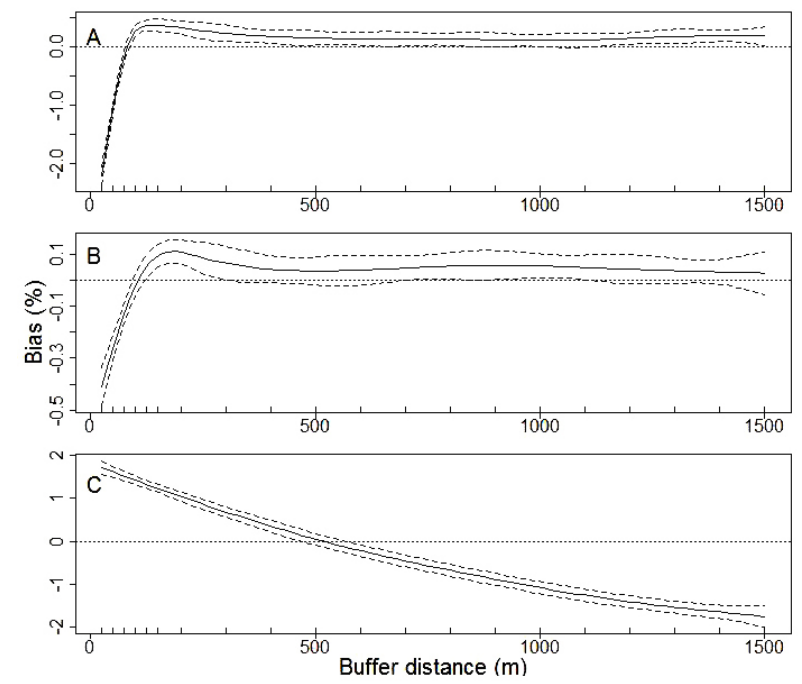
Table 1. Distribution of assigned and unassigned North American Breeding Bird Survey routes and study area extent based on the portion of boreal Canada for which anthropogenic disturbance data (Pasher et al. 2013) are available. BCR indicates bird conservation region.

\begin{tabular}{|c|c|c|c|c|c|c|c|c|}
\hline \multirow[b]{2}{*}{ Prov./BCR } & \multirow[b]{2}{*}{ BCR Name } & \multirow[b]{2}{*}{ Total area (ha) } & \multicolumn{2}{|c|}{ Forest loss } & \multicolumn{2}{|c|}{ Forest fires } & \multicolumn{2}{|c|}{ Anthropogenic } \\
\hline & & & Area (ha) & $\%$ & Area (ha) & $\%$ & Area (ha) & $\%$ \\
\hline \multicolumn{9}{|l|}{ Alberta } \\
\hline 6 & Boreal Taiga Plains & $44,565,941$ & $2,596,731$ & 5.8 & $1,080,886$ & 2.4 & $4,944,239$ & 11.1 \\
\hline 7 & Taiga Shield and Hudson Plains & 880,757 & 175,724 & 20.0 & 165,576 & 18.8 & 43 & 0.0 \\
\hline 8 & Boreal Softwood Shield & 701,372 & 126,032 & 18.0 & 108,001 & 15.4 & 0 & 0.0 \\
\hline \multicolumn{9}{|c|}{ British Columbia } \\
\hline \multicolumn{8}{|l|}{ Manitoba } & 11.2 \\
\hline 6 & Boreal Taiga Plains & $12,712,031$ & 134,998 & 1.1 & 41,928 & 0.3 & 245,729 & 1.9 \\
\hline 7 & Taiga Shield and Hudson Plains & $20,129,996$ & 556,897 & 2.8 & 304,955 & 1.5 & 3257 & 0.0 \\
\hline 8 & Boreal Softwood Shield & $23,381,202$ & 929,448 & 4.0 & 656,853 & 2.8 & 162,643 & 0.7 \\
\hline 12 & Boreal Hardwood Transition & $1,531,010$ & 42,586 & 2.8 & 4,965 & 0.3 & 239,846 & 15.7 \\
\hline \multicolumn{9}{|c|}{ Newfoundland \& Labrador } \\
\hline 7 & Taiga Shield and Hudson Plains & $22,236,766$ & 217,880 & 1.0 & 75,878 & 0.3 & 5945 & 0.0 \\
\hline 8 & Boreal Softwood Shield & $15,160,748$ & 223,327 & 1.5 & 11,086 & 0.1 & 44,228 & 0.3 \\
\hline \multicolumn{9}{|c|}{ Northwest Territories } \\
\hline 6 & Boreal Taiga Plains & $50,239,531$ & 650,606 & 1.3 & 512,449 & 1.0 & 14,673 & 0.0 \\
\hline 7 & Taiga Shield and Hudson Plains & $32,721,927$ & 905,693 & 2.8 & 755,816 & 2.3 & 1549 & 0.0 \\
\hline \multicolumn{9}{|l|}{ Ontario } \\
\hline 7 & Taiga Shield and Hudson Plains & $26,159,946$ & 102,645 & 0.4 & 9,075 & 0.0 & 16,499 & 0.1 \\
\hline 8 & Boreal Softwood Shield & $43,539,104$ & $2,039,842$ & 4.7 & 701,457 & 1.6 & $4,529,140$ & 10.4 \\
\hline 12 & Boreal Hardwood Transition & $20,511,349$ & 844,955 & 4.1 & 15,196 & 0.1 & $1,429,820$ & 7.0 \\
\hline \multicolumn{9}{|l|}{ Québec } \\
\hline 7 & Taiga Shield and Hudson Plains & $56,048,474$ & 930,106 & 1.7 & 482,460 & 0.9 & 10,357 & 0.0 \\
\hline 8 & Boreal Softwood Shield & $46,684,980$ & $2,616,705$ & 5.6 & $1,064,895$ & 2.3 & $5,295,622$ & 11.3 \\
\hline 12 & Boreal Hardwood Transition & $17,338,057$ & 966,128 & 5.6 & 175,502 & 1.0 & $1,073,063$ & 6.2 \\
\hline \multicolumn{9}{|c|}{ Saskatchewan } \\
\hline 6 & Boreal Taiga Plains & $17,806,415$ & 718,980 & 4.0 & 376,988 & 2.1 & 501,094 & 2.8 \\
\hline 7 & Taiga Shield and Hudson Plains & $4,482,935$ & 581,416 & 13.0 & 472,096 & 10.5 & 400 & 0.0 \\
\hline 8 & Boreal Softwood Shield & $18,877,740$ & $3,107,524$ & 16.5 & $2,544,882$ & 13.5 & 28,472 & 0.2 \\
\hline
\end{tabular}

When compared with rates of forest loss at the strata level, bias in representation along BBS routes was larger than that observed in comparisons between BBS routes and degree blocks (Fig. 3). Forest loss was underrepresented in the BBS network in BCRs 6 , 7 , and 8 (Fig. 3A, 3B, and 3C, respectively), but the magnitude of the bias was variable among BCRs. Based on absolute values, bias along BBS routes on average was lowest in BCR 8 (mean $=1.04 \%$, $\mathrm{SD}=0.69 \%)$ and highest in BCR 7 (mean $=3.13 \%, \mathrm{SD}=6.09 \%)$, but was variable among provinces (Fig. 3). The largest biases were an underrepresentation of forest loss along BBS routes in Alberta BCR 6 by $2.9 \%$ (Fig. 3A), an overrepresentation by $6.7 \%$ along BBS routes in Québec BCR 7 (Fig. 3B), an underrepresentation along BBS routes in Québec BCR 8 by $1.5 \%$ (Fig. 3C), and a $2.1 \%$ overrepresentation of forest loss along BBS routes in Manitoba BCR 12.

Overall, bias along the entire road network was of a similar magnitude as it was along BBS routes (Fig. 3A-C; $t=-0.92$, DF $=20, P=0.37$ ). Although the overall biases along the road and BBS networks were similar, a few noteworthy biases exist along the road network, including underrepresentation of forest loss in Alberta BCR 7 (-19.7\%, Fig. 3B), Saskatchewan BCR 7 (-7.8\%, Fig. 3B), Saskatchewan BCR 8 (-5.4\%, Fig. 3C), and overrepresentation of forest loss in Ontario BCR 8 (5.5\%, Fig. 3C).

\section{Forest fires}

Similar to overall forest loss, bias in representation of forest fires within degree blocks varied between BBS strata $\left(\mathrm{F}_{17,438}=2.79, P\right.$ $<0.001)$. However, only one stratum showed substantial bias in representation of forest fires within degree blocks (Table A1.2). Forest fires were overrepresented along BBS routes in Québec BCR $7(\beta=13.42 \%, \mathrm{SE}=2.30, t=5.84, P \leq 0.001)$. In addition to strata-level biases, a nonlinear relationship between bias and distance from road $(\mathrm{F}=24.23$, edf $=5.78, P<0.001)$ suggested that disturbance from forest fires was underrepresented at distances below $100 \mathrm{~m}$ and slightly overrepresented from $\sim 100-300$ m (Fig. 2B).

Similar to forest loss, forest fires were also generally underrepresented along the BBS network compared with the strata in which they were located (Fig. 4). The similarity in results was because of a strong correlation in the biases related to forest loss and forest fire $(\mathrm{r}=0.97, P<0.001)$, suggesting that the majority of forest loss was driven by forest fires. Based on absolute values, bias along BBS routes on average was lowest in BCR 12 $($ mean $=0.43 \%, \mathrm{SD}=0.51 \%)$ and highest in BCR 7 (mean $=$ $5.13 \%, \mathrm{SD}=7.56 \%$ ), but was variable amongst provinces (Fig. 4). The largest biases were an underrepresentation of forest fire along BBS routes in Alberta BCR 6 by $1.9 \%$ (Fig. 4A), a 16.7\% overrepresentation along BBS routes in Québec BCR 7 (Fig. 4B), 
Fig. 3. Overall bias in representation of forest "loss" along North American Breeding Bird Survey (BBS) routes compared with the proportion of forest loss (2000-2012) in BBS strata within the full BBS network and the road network as a whole in (A) bird conservation area 6 (BCR 6; Boreal Plains), (B) BCR 7 (Taiga Shield and Hudson Plains), and (C) BCR 8 (Boreal Softwood Shield). An asterisk (*) indicates that missing BBS network bars are because of no BBS coverage within the associated stratum and not zero values.
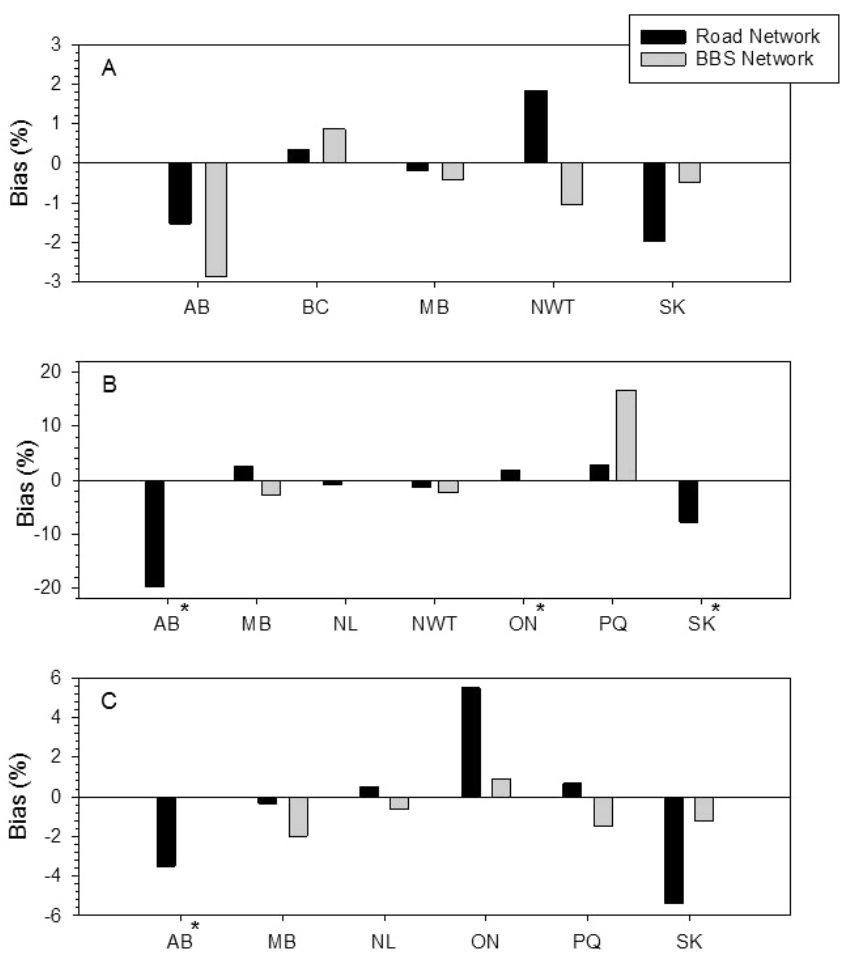

a 2\% underrepresentation along BBS routes in Manitoba BCR 8 (Fig. 4C), and a $2.1 \%$ overrepresentation of forest fires along BBS routes in Manitoba BCR 12.

Overall, bias in representation of forest fires along the entire road network was of a magnitude similar to that in the BBS network (Fig. 4A-C; $t=-0.59, \mathrm{DF}=16, P=0.56$ ). The most noteworthy biases along the road network included underrepresentation of forest fires in Alberta (1.9\%) and Saskatchewan BCR $6(1.6 \%$; Fig. 4A), Alberta (18.8\%) and Saskatchewan BCR 7 (6.5\%; Fig. 4B), and Saskatchewan BCR $8(4.3 \%$; Fig. 4C), and overrepresentation of forest fires in the Northwest Territories BCR 6 (1.8\%; Fig. 4A).

\section{Anthropogenic disturbances}

Bias in representation of anthropogenic disturbance between routes and degree blocks also differed significantly between strata $\left(\mathrm{F}_{17,438}=6.53, P<0.001\right)$. Five strata had BBS routes that were not representative of the degree blocks they were in (Table A1.3). Anthropogenic disturbance was overrepresented along BBS routes in BCR 6 in Alberta $(\beta=9.89 \%, \mathrm{SE}=1.41, \mathrm{t}=7.01, P<$
Fig. 4. Overall bias in representation of forest fires along North American Breeding Bird Survey (BBS) routes compared against proportion of forest burned (2000-2012) in BBS strata within the full BBS network and the road network as a whole in (A) bird conservation area 6 (BCR 6; Boreal Plains), (B) BCR 7 (Taiga Shield and Hudson Plains), and C) BCR 8 (Boreal Softwood Shield). An asterisk (*) indicates that missing BBS network bars are because of no BBS coverage within the associated stratum and not zero values.
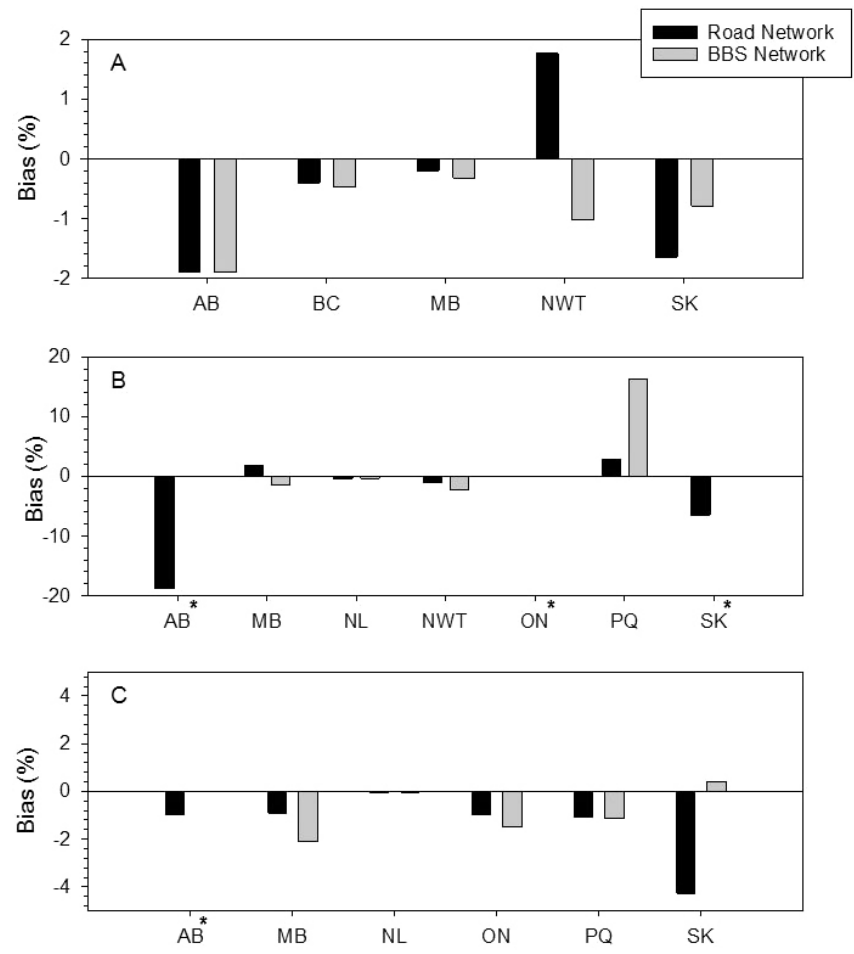

$0.001)$ and British Columbia $(\beta=12.88 \%, \mathrm{SE}=5.25, t=2.46, P$ $=0.01)$, BCR 12 in Manitoba $(\beta=21.17 \%, \mathrm{SE}=4.54, t=4.66$, $P<0.001)$ and Ontario $(\beta=3.25 \%, \mathrm{SE}=1.48, t=2.19, P=0.03)$, and BCR 8 in Ontario $(\beta=8.69 \%, \mathrm{SE}=1.76, t=4.92, \mathrm{P}<0.001)$. In addition to strata-level biases, a near-linear negative relationship between bias and distance from road $(F=306.4$, edf $=3.62, P<0.001)$ suggested anthropogenic disturbance was overrepresented at distances roughly below $515 \mathrm{~m}$ and underrepresented thereafter (Fig. 2C).

Bias in representation of anthropogenic disturbances was large (Fig. 5) and much larger than that in overall forest loss or forest fires (Fig. 3 and Fig. 4, respectively). Excluding an underrepresentation of anthropogenic disturbances in BCR 12 in Québec $(1.8 \%)$, all biases were an overrepresentation of anthropogenic disturbances. Based on absolute values, bias along BBS routes on average was lowest in BCR 7 (mean $=6.02 \%, \mathrm{SD}$ $=4.85 \%)$ and highest in BCR $6($ mean $=15.45 \%, \mathrm{SD}=22.83 \%)$, but was highly variable among provinces (Fig. 5). In BCR 6, biases were under $5 \%$ for Manitoba, Northwest Territories, and Saskatchewan, but greater than $17 \%$ otherwise (Fig. 5A). In BCR 
Fig. 5. Overall bias in representation of anthropogenic disturbances along North American Breeding Bird Survey (BBS) routes compared against proportion of the BBS strata comprised of anthropogenic disturbances (circa 2008-2010) within the full BBS network and the road network as a whole in (A) bird conservation area 6 (BCR 6; Boreal Plains), (B) BCR 7 (Taiga Shield and Hudson Plains), and (C) BCR 8 (Boreal Softwood Shield). An asterisk (*) indicates that missing BBS network bars are because of no BBS coverage within the associated stratum and not zero values.
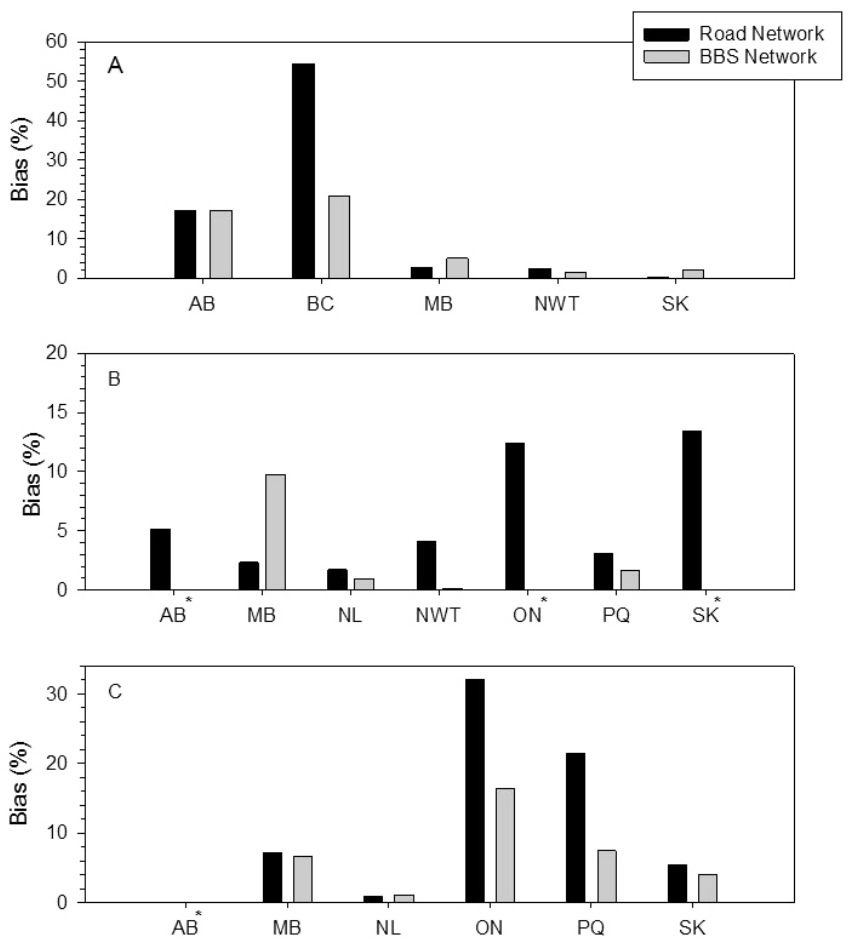

7, the most significant bias was a $9.7 \%$ overrepresentation of anthropogenic disturbances along BBS routes in Manitoba (Fig. $5 \mathrm{~B})$. Within BCE 8 , the only province with $<2 \%$ bias in anthropogenic disturbance representation was Newfoundland; there was $4 \%-16.3 \%$ overrepresentation in all other provinces (Fig. 5C). In BCR 12, anthropogenic disturbance was overrepresented by $2.8 \%$ and $19.6 \%$ in Ontario and Manitoba, respectively.

Overall, bias along the entire road network was of a magnitude similar to that of the BBS routes (Fig. $5 \mathrm{~A}-\mathrm{C} ; t=1.86, \mathrm{DF}=16$, $P=0.08$ ). Although the overall biases along the road and BBS networks were similar, biases along the road network were substantially greater in British Columbia BCR 6 (54.5\% versus $21.0 \%$ for the road versus BBS networks, respectively; Fig. 5A), lower in Manitoba BCR 7 (2.3\% versus 9.7\%; Fig. 5B), and substantially higher in BCR 8 in Ontario (32.0\% versus $16.3 \%$; Fig. 5C) and Québec (21.5\% versus 7.5\%; Fig. 5C). In BCR 12, bias in representing anthropogenic disturbances was substantially greater along the road network $(30.3 \%)$ than along BBS routes $(19.6 \%)$.

\section{DISCUSSION}

Natural and anthropogenic disturbances are a significant feature of the Canadian boreal forest. Using the data of Hansen et al. (2013) and the Canadian Wildland Fire Information System (2014), we estimated that $0.4 \%-20.0 \%$ of individual BBS strata were disturbed between 2002 and 2012. Disturbance rates were highest in BCRs 7 and 8 in Alberta $(20.0 \%$ and $18.0 \%$, respectively) and Saskatchewan (13.0\% and $16.5 \%$, respectively), where large forest fires contributed to the majority $(82.5 \%)$ of the forest change with more than 3.29 million hectares burned between 2002 and 2012. Thus, the background rates of habitat change within the study period were as high as $1.6 \%-1.7 \% \mathrm{y}^{-1}$ and just slightly below the burn rates of $>2 \% \mathrm{y}^{-1}$ reported by Héon et al. (2014) on smaller geographic scales in the same region. Furthermore, we found that the ability of the BBS and road networks to represent these disturbance rates was variable depending upon the spatial scale of comparison and stratum involved.

Several previous studies have found variable bias in habitat representation and/or disturbance rates (Bart et al. 1995, Keller and Scallan 1999, Lawler and O'Connor 2004, Betts et al. 2007, Harris and Haskell 2007, Matsuouka et al. 2011, Veech et al. 2012). Our analyses suggested that bias was greatest in areas immediately along roadsides, which corresponds to work by Keller and Scallan (1999), who found a greater rate of increase in urban area along roadsides $(0-200 \mathrm{~m})$ than off-road areas (200-1600 m) in Maryland. In contrast, several previous studies have described relatively low bias in habitat representation along BBS routes (Lawler and O'Connor 2004, Veech et al. 2012). Across studies, biases appear to vary between physiographic regions and also appear to be dependent on scales of geographic analyses; studies that use smaller buffers such as ours and those by Keller and Scallan (1999) and Betts et al. (2007) appear to be more likely to identify biases. Biologically, smaller scales are likely more relevant because the majority of boreal species are effectively detectable at distances below $120 \mathrm{~m}$ (Bart et al. 1995, Matsuoka et al. 2012). Furthermore, differences in geographic scales of comparison and units of measure make it difficult to directly compare the magnitude of bias between studies; thus, future work may benefit from reporting biases over multiple distance classes as we have done here. Despite scale differences, our results are generally of a magnitude similar to biases reported by Betts et al. (2007) in New Brunswick (13.5\%-22.5\% bias) and biases of up to $30 \%$ in representing some cover types in the boreal forest (Matsuoka et al. 2011). Similarly, Veech et al. (2012) showed biased representation of some developed landcover classes in the $2 \%-6 \%$ range, which falls at the low range of overrepresentation of anthropogenic disturbances we describe.

In general, the biases we observed in representation of forest loss, forest fires, and anthropogenic disturbance followed our a priori hypotheses. Specifically, anthropogenic disturbances were overrepresented in southern BBS strata, whereas forest fires were generally underrepresented. However, whereas we predicted that forest fires would be underrepresented primarily in northern strata, they were in fact almost uniformly underrepresented in every stratum. In comparing representation of disturbances along BBS routes with that in the degree blocks, we also found support for our hypothesis that anthropogenic disturbances would be disproportionately represented in areas immediately adjacent to roads, with declining representation away from roads. 
At the level of the degree block, BBS routes were reasonably representative of disturbance rates. With the exception of BCR 7 in Québec, BBS routes represented rates of forest loss and forest fire within degree blocks after accounting for distance from the road. Anthropogenic disturbances were overrepresented in BBS routes relative to degree blocks in 3 out of 17 strata. Somewhat larger biases were observed when comparing BBS routes or the road network against strata, particularly with regard to anthropogenic disturbances. Although simulation studies would be needed to determine exactly what degree of bias is biologically relevant to trend estimates, 3\%-6\% biases alone might yield a $5 \%-10.5 \%$ bias in trend over 20 years if we extrapolate by assuming a 1:1 relationship between habitat amount and trend. Larger biases in trend estimates would obviously result in strata where, e.g., fire is overrepresented by $>16 \%$ (i.e. BCR 7 in Québec) or in the many strata in which anthropogenic disturbances are overrepresented by up to $21 \%$. Trend estimates for species reliant on either mature or old forest and early successional postfire habitats may be particularly sensitive to these biases. For example, Betts et al. (2007) and S. L. Van Wilgenburg, K. Hobson, K. Kardynal, and E. Beck (unpublished manuscript) showed that trends of species associated with closed canopy forests responded linearly to the amount of disturbance in survey areas (BBS routes and forest stands, respectively). Furthermore, Betts et al. (2007) found differing degrees of bias in representation of change in mature forest cover between two survey periods in which BBS trend estimates also differed. As a result, Betts et al. (2007) suggested that population declines in Blackburnian Warbler (Setophaga fusca) in New Brunswick may have been masked by biased representation of habitat change in one of the time periods investigated. Thus, future analyses examining the sensitivity of BBS trends to the degree of variation in bias we observed would be fruitful.

We found nonlinear relationships between bias in representation of forest disturbances and distance from the road. Forest loss on average was underrepresented by as much as $2.5 \%$ within $75 \mathrm{~m}$ from the road. It is possible that forest loss and disturbance due to forest fires are underrepresented along roadsides because the majority of the disturbance along roads occurs during road construction, with the habitat remaining relatively static thereafter. Furthermore, where logging occurs, buffer strips are occasionally left along roadsides (Lansky 1992, Betts et al. 2007). Additionally, bias in road placement may lead to roads being placed in upland forest types in which fire severity tends to result in lower tree mortality than it does in lowland forest (Cumming 2001), thus causing less disturbance along roads. Regardless of the mechanistic explanation, these results suggest that trend estimates from roadside sampling may be biased and therefore may not accurately reflect trends at the strata level.

Our spline curves suggest that much of this bias could be assessed via off-road sampling beyond approximately 300-500 m, where confidence intervals from our curves overlap zero, from the road. Thus, we suggest our results could be used to design off-road sampling to either augment roadside sampling or to test whether the trends from the roadside sampling frame are reflective of trends in bird populations in the off-road, e.g., beyond $300 \mathrm{~m}$, sampling frame.

\section{CONCLUSION}

Our study has implications for conservation decisions grounded on BBS trend estimates as well as for monitoring design. First, our study implies that there is a risk of inaccurate status assessment for boreal forest birds. Simulations by Harris and Haskell (2007) suggest that habitat and disturbance biases can cause substantial misrepresentation of rates of population change, with one simulation suggesting underestimation of a population increase by $2.57 \% \mathrm{y}^{-1}$. Bias in that range could be sufficient to substantially change species status assessments. Short- and long-term trend estimates in the boreal forest are likely also affected because numerous species preferentially use specific age classes of forest (Hobson and Bayne 2000, Cumming and Diamond 2002, Schieck and Song 2006). Furthermore, annual area burned has increased in the Canadian boreal forest over the last four decades (Gillett et al. 2004, Kasischke and Turetsky 2006, Lehsten et al. 2013). The resulting increase in early successional habitat should result in increased carrying capacity for species associated with those habitats and thus tend to result in positive species trends. Given that fire is generally underrepresented in the road network, potential positive population responses to increased early postfire habitat could go unnoticed or underestimated by roadside sampling. Olive-sided Flycatcher and Common Nighthawk (Chordeiles minor) are notable examples of species that have been listed as threatened in Canada, based in part on BBS trend estimates, that are associated with early postfire habitats within the boreal forest (Schieck and Song 2006); thus, they are species for which biases could in theory cause inflated estimates of population decline. The increase in the average area of forest burned annually in Canada also suggests a concomitant decrease in the area of mature forests, which has previously been shown to influence trends of species associated with old forest habitats (Betts et al. 2007). Indeed, the $2.2 \% \mathrm{y}^{-1}$ bias observed by Betts et al. (2007) is in a similar range to many of the biases we report, thus making it plausible that the biases we observed could impede valid extrapolation of trends to the population level. Accounting for these biases will also be important for future status assessments because annual area burned is projected to possibly double by the middle of the 21 st century (Balshi et al 2009), which combined with ongoing industrial expansion (Schnieder et al. 2003, Mahon et al. 2014) has been projected to cause regional population goal shortfalls for several boreal forest birds (Mahon et al. 2014).

Although we point to biases in representation along established BBS routes, it is important to note that the greatest impediment to monitoring is the current lack of sampling in the north. Several strata such as BCR 8 in Saskatchewan have only recently had BBS routes established and are yet to have any BBS routes run. As such, the biases we report here underestimate the overall bias in data contributing to trend analyses because our results represent the degree of bias that would occur if sampling coverage were complete. Thus, we recommend that attempts be made to sample existing, but not presently sampled, BBS routes in remote regions, particularly BCR 8 in Saskatchewan and Manitoba, remote pockets of BCR 6 in Northwest Territories and northern British Columbia, and any routes in BCR 7 across Canada. In addition, it would be useful to investigate how the addition of more complete road network layers may change our results and whether tertiary roads or trails may reduce bias in the sampling frame. 
Caution would be necessary in implementing monitoring using some of these smaller roads and trails, however, because some may become abandoned or may be purposefully closed (e.g., forestry roads/trails) to protect other resource values.

Given the range of variation in disturbance rates and the biases that we describe, combined with finer scale analyses of burn rates (Héon et al. 2014) and anthropogenic disturbance (Pasher et al. 2013), simply sampling more BBS routes may not adequately capture variation in disturbance rates. Therefore, we recommend that new BBS routes should be established in all degree blocks for which there is appropriate road coverage. Furthermore, we suggest that spatial stratification methods such as generalizedrandom tessellation (Stevens and Olsen 2004) or systematic sampling be investigated as methods of selecting degree blocks for sampling within a given year to capture variation in disturbance rates in an unbiased fashion within the limitations of the road network. In addition, rotating panel designs (see Gitzen et al. 2012) should be investigated as a way of spreading limited effort across the spatially stratified panels within a given year.

Unfortunately, the lack of volunteers, logistics, narrow roads, and heavy industrial truck traffic may make it difficult to sufficiently sample the boreal forest. It may, therefore, be necessary to examine the possibility of using paid staff or reimbursing volunteers to increase sampling in northern areas. Finally, there are several strata in which the boreal road network likely has too little road coverage to accommodate BBS sampling at all, including virtually all of BCR 7. In addition, roads in several regions may be too dangerous to sample via roadside sampling. Thus, it is apparent that trends for these strata will require reliance either on off-road point counts or BBS style surveys (e.g., via all-terrain vehicle) such as those conducted for bird atlases (Blancher et al. 2009), dedicated regional monitoring programs (e.g., Machtans et al. 2014), or reliance on trends from the Christmas Bird Count (Niven et al. 2004) or migration monitoring in combination with methods to infer catchment areas (Hobson et al. 2015). As such, it would be beneficial to build on other work (e.g., Sólymos et al. 2013, Amundson et al. 2014) to develop and validate a framework for trend estimation from combining on-road and off-road point counts.

Responses to this article can be read online at: http://www.ace-eco.org/issues/responses.php/777

\section{Acknowledgments:}

We thank J. Pasher, E. Seed, and J. Duffe (Environment Canada) for providing access to the Boreal Ecosystem Anthropogenic Disturbance layers. M. A. Hudson (Environment Canada) provided GIS layers of BBS routes. K. Whillans and L. Keillor-Faulkner (Sir Sanford Fleming College) provided useful comments on earlier versions of the work. O. Trottier (Canada Centre for Mapping and Earth Observation) provided useful information on road network layers. This manuscript benefitted from useful comments by the $K$. Hobson, the subject editor, and two anonymous reviewers. We thank the Population Assessment Unit (PNR) of Environment Canada for additional logistical support and fruitful discussions (S. Song) that contributed of the direction of this work.

\section{LITERATURE CITED}

Amundson, C. L., J. A. Royle, and C. M. Handel. 2014. A hierarchical model combining distance sampling and time removal to estimate detection probability during avian point counts. Auk 131:476-494. http://dx.doi.org/10.1642/AUK-14-11.1

Avian Monitoring Review Steering Committee. 2012. Environment Canada avian monitoring review: final report. Environment Canada, Ottawa, Ontario, Canada. [online] URL: http://publications.gc.ca/site/eng/422608/publication.html

Balshi, M. S., A. D. McGuire, P. Duffy, M. Flannigan, J. Walsh, and J. Melillo. 2009. Assessing the response of area burned to changing climate in western boreal North America using a Multivariate Adaptive Regression Splines (MARS) approach. Global Change Biology 15:578-600. http://dx.doi.org/10.1111/ j.1365-2486.2008.01679.x

Bart, J., M. Hofschen, and B. G. Peterjohn. 1995. Reliability of the Breeding Bird Survey: effects of restricting surveys to roads. Auk 112:758-761.

Belleau, A., Y. Bergeron, A. Leduc, S. Gauthier, and A. Fall. 2007. Using spatially explicit simulations to explore size distribution and spacing of regenerating areas produced by wildfires: recommendations for designing harvest agglomerations for the Canadian boreal forest. Forestry Chronicle 83:72-83. http://dx. doi.org/10.5558/tfc83072-1

Bergeron, Y., M. Flannigan, S. Gauthier, A. Leduc, and P. Lefort. 2004. Past, current and future fire frequency in the Canadian boreal forest: implications for sustainable forest management. Ambio 33:356-360. http://dx.doi.org/10.1579/0044-7447-33.6.356

Betts, M. G., D. Mitchell, A. W. Diamond, and J. Bêty. 2007. Uneven rates of landscape change as a source of bias in roadside wildlife surveys. Journal of Wildlife Management 71:2266-2273. http://dx.doi.org/10.2193/2006-004

Blancher, P. J., R. D. Phoenix, D. S. Badzinski, M. D. Cadman, T. L. Crewe, C. M. Downes, D. Fillman, C. M. Francis, J. Hughes, D. J. T. Hussell, D. Lepage, J. D. McCracken, N. K. McNicol, B. A. Pond, R. K. Ross, R. Russell, L. A. Venier, and R. C. Weeber. 2009. Population trend status of Ontario's forest birds. Forestry Chronicle 85:184-201. http://dx.doi.org/10.5558/tfc85184-2

Bled F., J. Sauer, K. Pardieck, P. Doherty, and J. A. Royle. 2013. Modeling trends from North American Breeding Bird Survey data: a spatially explicit approach. PLoS ONE 8:e81867. http:// dx.doi.org/10.1371/journal.pone.0081867

Canadian Wildland Fire Information System. 2014. National fire database: fire polygon data. Natural Resources Canada, Northern Forestry Centre, Edmonton, Alberta, Canada. [online] URL: http://cwfis.cfs.nrcan.gc.ca/datamart

Crewe, T. L., J. D. McCracken, P. D. Taylor, D. Lepage, and A. E. Heagy. 2008. The Canadian migration monitoring network: tenyear report on monitoring landbird population change. CMMNRCSM Scientific Technical Report \#1. Bird Studies Canada, Port Rowan, Ontario, Canada.

Cumming, E. E., and A. W. Diamond. 2002. Songbird community composition versus forest rotation age in Saskatchewan boreal mixedwood forest. Canadian Field-Naturalist 116:69-75. 
Cumming, E. E., K. A. Hobson, and S. L. Van Wilgenburg. 2001. Breeding bird declines in the boreal forest fringe of western Canada: insights from long-term BBS routes. Canadian FieldNaturalist 115:425-435.

Cumming, S. G. 2001. Forest type and wildfire in the Alberta boreal mixedwood: what do fires burn? Ecological Applications 11:97-110. http://dx.doi.org/10.1890/1051-0761(2001)011[0097: FTAWIT]2.0.CO;2

Gillett, N. P., A. J. Weaver, F. W. Zwiers, and M. D. Flannigan. 2004. Detecting the effect of climate change on Canadian forest fires. Geophysical Research Letters 31:L18211. http://dx.doi. org/10.1029/2004GL020876

Gitzen, R. A., J. J. Millspaugh, A. B. Cooper, and D. S. Licht, editors. 2012. Design and analysis of long-term ecological monitoring studies. Cambridge University Press, Cambridge, UK. http://dx.doi.org/10.1017/cbo9781139022422

Hansen, M. C., P. V. Potapov, R. Moore, M. Hancher, S. A. Turubanova, A. Tyukavina, D. Thau, S. V. Stehman, S. J. Goetz, T. R. Loveland, A. Kommareddy, A. Egorov, L. Chini, C. O. Justice, and J. R. G. Townshend. 2013. High-resolution global maps of $21^{\text {st }}$-century forest cover change. Science 342:850-853. http://dx.doi.org/10.1126/science.1244693

Harris, J. B. C., and D. G. Haskell. 2007. Land cover sampling biases associated with roadside bird surveys. Avian Conservation and Ecology 2(2):12. [online] URL: http://www.ace-eco.org/vol2/ iss $2 / \operatorname{art} 12 /$

Héon, J., D. Arseneault, and M.-A. Parisien. 2014. Resistance of the boreal forest to high burn rates. Proceedings of the National Academy of Sciences of the United States of America 111:13888-13893. http://dx.doi.org/10.1073/pnas.1409316111

Hobson, K. A., and E. Bayne. 2000. The effects of stand age on avian communities in aspen-dominated forests of central Saskatchewan, Canada. Forest Ecology and Management 136:121-134. http://dx.doi.org/10.1016/S0378-1127(99)00287-X

Hobson, K. A., E. M. Bayne, and S. L. Van Wilgenburg. 2002. Large-scale conversion of forest to agriculture in the boreal plains of Saskatchewan. Conservation Biology 16:1530-1541. http://dx. doi.org/10.1046/j.1523-1739.2002.01199.x

Hobson, K. A., S. L. Van Wilgenburg, E. H. Dunn, D. J. T. Hussell, P. D. Taylor, and D. M. Collister. 2015. Predicting origins of passerines migrating through Canadian migration monitoring stations using stable-hydrogen isotope analyses of feathers: a new tool for bird conservation. Avian Conservation and Ecology 10 (1):3. http://dx.doi.org/10.5751/ACE-00719-100103

Kasischke, E. S., and M. R. Turetsky. 2006. Recent changes in the fire regime across the North American boreal region-spatial and temporal patterns of burning across Canada and Alaska. Geophysical Research Letters 33:L09703. http://dx.doi. org/10.1029/2006GL025677

Keller, C. M. E., and J. T. Scallan. 1999. Potential roadside biases due to habitat changes along Breeding Bird Survey routes. Condor 101:50-57. http://dx.doi.org/10.2307/1370445

Lansky, M. 1992. Beyond the beauty strip. Tilbury House, Gardiner, Maine, USA.
Lawler, J. J., and R. J. O'Connor. 2004. How well do consistently monitored breeding bird survey routes represent the environments of the conterminous United States? Condor 106:801-814. http://dx.doi.org/10.1650/7472

Lehsten, V., W. J. de Groot, M. Flannigan, C. George, P. Harmand, and H. Balzter. 2014. Wildfires in boreal ecoregions: evaluating the power law assumption and intra-annual and interannual variations. Journal of Geophysical Research: Biogeosciences 119:14-23. http://dx.doi.org/10.1002/2012JG002252

Machtans, C. S., K. J. Kardynal, and P. A. Smith. 2014. How well do regional or national Breeding Bird Survey data predict songbird population trends at an intact boreal site? Avian Conservation and Ecology 9(1):5. http://dx.doi.org/10.5751/ ACE-00649-090105

Mahon, C. L., E. M. Bayne, P. Sólymos, S. M. Matsuoka, M. Carlson, E. Dzus, F. K. A. Schmiegelow, S. G. Cumming, and S. J. Song. 2014. Does expected future landscape condition support proposed population objectives for boreal birds? Forest Ecology and Management 312:28-39. http://dx.doi.org/10.1016/j.

foreco.2013.10.025

Martin, J., W. M. Kitchens, and J. E. Hines. 2007. Importance of well-designed monitoring programs for the conservation of endangered species: case study of the Snail Kite. Conservation Biology 21:472-481. http://dx.doi.org/10.1111/j.1523-1739.2006.00613. $\mathrm{x}$

Matsuoka, S. M., E. M. Bayne, P. Sólymos, P. C. Fontaine, S. G. Cumming, F. K. A. Schmiegelow, and S. J. Song. 2012. Using binomial distance-sampling models to estimate the effective detection radius of point-count surveys across Boreal Canada. Auk 129:268-282. http://dx.doi.org/10.1525/auk.2012.11190

Matsuoka, S., P. Sólymos, T. Fontaine, E. Bayne. 2011. Roadside surveys of boreal forest birds: how representative are they and how can we improve current sampling? Report to Environment Canada, Canadian Wildlife Service. University of Alberta, Edmonton, Alberta, Canada. [online] URL: http://www.borealbirds.ca/files/ BAM_Report_on_Roadside_Survey_Bias_for_EC.pdf

Natural Resources Canada. 2011. CanVec v8.0. Natural Resources Canada, Earth Science Sector, Centre for Topographic Information, Sherbrooke, Québec, Canada. [online] URL: http:// geogratis.gc.ca/api/en/nrcan-rncan/ess-sst/-/(urn:iso:series)canvec

Niven, D. K., J. R. Sauer, G. S. Butcher, and W. A. Link. 2004. Christmas Bird Count provides insights into population change in land birds that breed in the boreal forest. American Birds 58:10-20.

O'Connor, R. J., E. Dunn, D. H. Johnson, S. L. Jones, D. Petit, K. Pollock, C. R. Smith, J. L. Trapp, and E. Welling. 2000. A programmatic review of the North American breeding bird survey: report of a peer review panel. USGS Patuxent Wildlife Research Center, Laurel, Maryland, USA. [online] URL: http://www.pwrc. usgs.gov/bbs/bbsreview/

Pasher, J., E. Seed, and J. Duffe. 2013. Development of boreal ecosystem anthropogenic disturbance layers for Canada based on 2008 to 2010 Landsat imagery. Canadian Journal of Remote Sensing 39:42-58. http://dx.doi.org/10.5589/m13-007 
$\mathrm{R}$ Development Core Team. 2014. R: a language and environment for statistical computing. R Project for Statistical Computing, Vienna, Austria. [online] URL: http://www.R-project.org/

Rice, J. 2003. Environmental health indicators. Ocean \& Coastal Management 46:235-259. http://dx.doi.org/10.1016/S0964-5691 (03)00006-1

Sauer, J. R., and W. A. Link. 2011. Analysis of the North American Breeding Bird Survey using hierarchical models. Auk 128:87-98. http://dx.doi.org/10.1525/auk.2010.09220

Schieck, J., and S. J. Song. 2006. Changes in bird communities throughout succession following fire and harvest in boreal forests of western North America: literature review and meta-analyses. Canadian Journal of Forest Research 36:1299-1318. http://dx.doi. org/10.1139/x06-017

Schindler, D. W., and P. G. Lee. 2010. Comprehensive conservation planning to protect biodiversity and ecosystem services in Canadian boreal regions under a warming climate and increasing exploitation. Biological Conservation 143:1571-1586. http://dx.doi.org/10.1016/j.biocon.2010.04.003

Schneider, R. R., J. B. Stelfox, S. Boutin, and S. Wasel. 2003. Managing the cumulative impacts of land uses in the Western Canadian Sedimentary Basin: a modeling approach. Conservation Ecology 7(1):8. [online] URL: http://www.consecol. org/vol7/iss1/art8

Sólymos, P., S. M. Matsuoka, E. M. Bayne, S. R. Lele, P. Fontaine, S. G. Cumming, D. Stralberg, F. K. A. Schmiegelow, and S. J. Song. 2013. Calibrating indices of avian density from nonstandardized survey data: making the most of a messy situation. Methods in Ecology and Evolution 4:1047-1058. http://dx.doi. org/10.1111/2041-210X.12106

Stevens, D. L., Jr., and A. R. Olsen. 2004. Spatially balanced sampling of natural resources. Journal of the American Statistical Association 99:262-278. http://dx.doi.org/10.1198/016214504000000250

Stralberg, D., S. M. Matsuoka, A. Hamann, E. M. Bayne, P. Sólymos, F. Schmiegelow, X. Wang, S. G. Cumming, and S. J. Song. 2015. Projecting boreal bird responses to climate change: the signal exceeds the noise. Ecological Applications 25: 52-69. http://dx.doi.org/10.1890/13-2289.1

Stocks, B. J., J. A. Mason, J. B. Todd, E. M. Bosch, B. M. Wotton, B. D. Amiro, M. D. Flannigan, K. G. Hirsch, K. A. Logan, D. L. Martell, and W. R. Skinner. 2002. Large forest fires in Canada, 1959-1997. Journal of Geophysical Research 107:8149. http://dx. doi.org/10.1029/2001JD000484

Van Wilgenburg, S. L., K. A. Hobson, E. M. Bayne, and N. Koper. 2013. Estimated avian nest loss associated with oil and gas exploration and extraction in the Western Canadian Sedimentary Basin. Avian Conservation and Ecology 8(2):9. http://dx.doi. org/10.5751/ACE-00585-080209
Veech, J. A., M. F. Small, and J. T. Baccus. 2012. Representativeness of land cover composition along routes of the North American Breeding Bird Survey. Auk 129:259-267. http:// dx.doi.org/10.1525/auk.2012.11242

Wells, J. V., and P. Blancher. 2011. Global role for sustaining bird populations. Pages 7-21 in J. V. Wells, editor. Boreal birds of North America: a hemispheric view of their conservation links and significance. Studies in Avian Biology no. 41. University of California Press, Berkeley, California, USA.

Wilson, S., E. M. Anderson, A. S. G. Wilson, D. F. Bertram, and P. Arcese. 2013. Citizen science reveals an extensive shift in the winter distribution of migratory Western Grebes. PLOS ONE 8 (6):e65408. http://dx.doi.org/10.1371/journal.pone.0065408

Wood, S. N. 2004. Stable and efficient multiple smoothing parameter estimation for generalized additive models. Journal of the American Statistical Association 99:673-686. http://dx.doi. org/10.1198/016214504000000980

Wood, S. N. 2011. Fast stable restricted maximum likelihood and marginal likelihood estimation of semiparametric generalized linear models. Journal of the Royal Statistical Society B: Series B 73(1):3-36. http://dx.doi.org/10.1111/j.1467-9868.2010.00749.x

Zuur, A. F., E. N. Ieno, N. J. Walker, A. Saveliev, and G. M. Smith. 2009. Mixed effects models and extensions in ecology with $R$. Springer, New York, New York, USA. http://dx.doi. org/10.1007/978-0-387-87458-6
Editor-in-Chief: Keith A.Hobson

Subject Editor: Erin Bayne
Sponsored by the Society of Canadian Ornithologists and Bird Studies Canada Parrainée par la Société des ornithologistes du Canada et Etudes d'oiseaux Canada

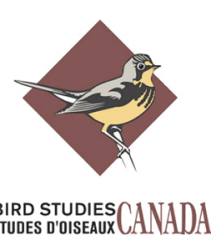


Appendix 1. Summary of generalized additive mixed model (GAMM) results examining bias in roadside measures of disturbance from overall forest loss, forest fires, and anthropogenic disturbances.

Table A1.1 Results of GAMM for bias in measurement of forest loss based on GIS analysis of 20 buffer distances between $25-1500 \mathrm{~m}$ along 455 BBS routes $(\mathrm{n}=9100)$.

\begin{tabular}{lllrrrr}
\hline Ecozone & BCR & Province & Estimate & SE & $t$-value & $p$-value \\
\hline Boreal Taiga Plains & 6 & AB & -0.64 & 0.53 & -1.21 & 0.23 \\
& & BC & -0.10 & 1.98 & -0.05 & 0.96 \\
& & MB & -0.24 & 1.06 & -0.22 & 0.82 \\
& & NWT & -1.06 & 1.21 & -0.88 & 0.38 \\
Boreal Hardwood Transition & & SK & -0.73 & 0.78 & -0.94 & 0.35 \\
& \multirow{2}{*}{12} & MB & 3.41 & 1.71 & 1.99 & 0.05 \\
& & ON & 0.45 & 0.56 & 0.81 & 0.42 \\
Boreal Softwood Shield & & PQ & -0.66 & 0.68 & -0.97 & 0.33 \\
& 8 & MB & -1.91 & 1.25 & -1.53 & 0.13 \\
& & NL & -0.24 & 1.010 & -0.24 & 0.81 \\
& & ON & -0.32 & 0.67 & -0.48 & 0.63 \\
Taiga Shield and Hudson Plains & 7 & MQ & -0.17 & 0.76 & -0.22 & 0.82 \\
& & SK & 0.92 & 1.34 & 0.68 & 0.49 \\
& & NL & -0.01 & 4.84 & -0.00 & 1.00 \\
& & NWT & -1.34 & 2.17 & 0.09 & 0.93 \\
& & PQ & 13.60 & 2.80 & -0.39 & 0.70 \\
& & & & & & 0.00 \\
\hline
\end{tabular}


Table A1.2 Results of GAMM for bias in measurement of forest fire based on GIS analysis of 20 buffer distances between $25-1500 \mathrm{~m}$ along 455 BBS routes $(\mathrm{n}=9100)$.

\begin{tabular}{lllrlrr}
\hline Ecozone & BCR & Province & Estimate & SE & $t$-value & $p$-value \\
\hline Boreal Taiga Plains & 6 & AB & -0.56 & 0.44 & -1.28 & 0.20 \\
& & BC & -0.27 & 1.63 & -0.17 & 0.87 \\
& & MB & -0.28 & 0.87 & -0.32 & 0.75 \\
& & NWT & -0.67 & 1.00 & -0.68 & 0.50 \\
Boreal Hardwood Transition & & SK & -0.81 & 0.64 & -1.27 & 0.21 \\
& & MB & -0.14 & 1.41 & -0.10 & 0.92 \\
Boreal Softwood Shield & & ON & -0.03 & 0.46 & -0.06 & 0.95 \\
& & PQ & -0.46 & 0.56 & -0.82 & 0.41 \\
& 8 & MB & -1.63 & 1.03 & -1.59 & 0.11 \\
& & NL & -0.06 & 0.83 & -0.08 & 0.94 \\
Taiga Shield and Hudson Plains & ON & -0.89 & 0.55 & -1.63 & 0.10 \\
& & ON & 0.35 & 0.62 & 0.56 & 0.57 \\
& & SK & 1.95 & 1.10 & 1.77 & 0.08 \\
& & NL & 0.00 & 3.98 & 0.00 & 1.00 \\
& NWT & -0.27 & 1.78 & -0.15 & 0.88 \\
& & -1.49 & 2.82 & -0.53 & 0.60 \\
& PQ & 13.42 & 2.30 & 5.84 & $<0.001$ \\
\hline
\end{tabular}


Table A1.3 Results of GAMM for bias in measurements of anthropogenic disturbance based on GIS analysis of 20 buffer distances between $25-1500 \mathrm{~m}$ along 455 BBS routes $(n=9100)$.

\begin{tabular}{lllrrrr}
\hline \hline Ecozone & BCR & Province & Estimate & SE & $t$-value & $p$-value \\
\hline Boreal Taiga Plains & 6 & AB & 9.89 & 1.41 & 7.01 & $<0.001$ \\
& & BC & 12.88 & 5.25 & 2.46 & 0.01 \\
& & MB & 3.77 & 2.80 & 1.34 & 0.18 \\
& & NWT & 0.98 & 3.21 & 0.30 & 0.76 \\
Boreal Hardwood Transition & \multirow{2}{*}{12} & SK & 1.69 & 2.06 & 0.82 & 0.41 \\
& & MB & 21.17 & 4.54 & 4.66 & $<0.001$ \\
& & ON & 3.25 & 1.48 & 2.19 & 0.03 \\
Boreal Softwood Shield & 8 & MB & -0.46 & 1.80 & -0.25 & 0.80 \\
& & NL & 0.98 & 3.32 & 1.05 & 0.29 \\
& & ON & 8.69 & 1.76 & 4.92 & $<0.001$ \\
& & PQ & 1.35 & 2.01 & 0.67 & 0.50 \\
Taiga Shield and Hudson Plains & 7 & MK & 2.64 & 3.56 & 0.74 & 0.46 \\
& & NB & 6.62 & 12.85 & 0.52 & 0.61 \\
& & NWT & 0.17 & 9.08 & 0.02 & 0.98 \\
& & PQ & 1.05 & 7.42 & 0.14 & 0.89 \\
\hline
\end{tabular}

